\title{
Beth Simone Noveck: \\ Wiki Government: How Technology Can Make Government Better, Democracy Stronger, and Citizens More Powerful Washington: Brookings Institution Press. 2009
}

\author{
Inka Salovaara
}

MedieKultur 2012, 52, 189-192

Published by SMID | Society of Media researchers In Denmark | www.smid.dk The online version of this text can be found open access at www.mediekultur.dk

The discussion about e-Governance has its roots in early theories of participatory democracy. It refers to a form of direct democracy that enables political actors like citizens, local communities, and nations to use web 2.0 tools on the national and international stage. Conceptually, e-Governance can be defined as an integrative concept for e-oriented methods in communicative and connected governing. This new approach has brought political governance into the social context of everyday life by allowing citizens and citizen-experts to act more as "partners" than subjects of political governance and democratic representation.

Wiki Government takes the e-Governance discussion one step further. The book explores the innovative process that led to the "Peer-to-Patent" pilot, a project in one of the US government bureaucracies at the beginning of Barack Obama's "Open Government" era.

The US Patent and Trademark Office (USPTO) is a government unit responsible for evaluating patent applications. Like many government bureaucracies, USPTO was overwhelmed and unable to deliver timely reviews for approval. With insufficient experts to evaluate the backlog of pending applications, the unit was on the verge of collapsing.

The logjam in the Patent Office offers a good example of the information deficit many government units face today. A thousand examiners of the USPTO's new technology section reviewed close to 70,000 new technology applications annually and another 90,000 were awaiting action. Most of the evaluators did not have the required expertise to evaluate a patent application and the process often resulted in "low quality" patents. Of particular concern was that information technology patents took at minimum 18 months to pro- 
cess. In a fast moving digital innovation scene, a patent application often became outdated before any action was taken. Hence, the book starts with the fact that the closed model of decision-making does not work in the increasingly complicated and expertise-demanding environment of today's political governance.

Although USPTO sounds distant to a European reader, the patent and trademark institution is one of the cornerstones of Western capitalism. As defined by Abraham Lincoln, "the patent system adds the fuel to the fire of genius." However, instead of advancing the accumulation of scientific knowledge, technological innovation and stimulating investment in new products, the USPTO was turning into a bureaucracy that was hampering the very process that it was supposed to enhance.

Government information systems are also big business in all Western countries. They are critical to all aspects of public policy and governmental operations. According to Gartner research, worldwide IT spending was estimated at $\$ 3.6$ trillion in 2011, which is a 5.1\% increase from the year 2010 ( $\$ 3.4$ trillion). In many cases the money invested has not produced the expected results, as systems have at best been mediocre.

The author, Beth Noveck, a Professor of Law at New York Law School, was the deputy chief technology officer 2009-2011 in Barack Obama's administration, which implemented ideas of more collaborative forms of governance. In the first chapters, she explores the set of web 2.0 tools the Peer-to-Patent project applied in order to improve the flow of USPTO patent examinations, leading the Open Government Initiative.

The Peer-to-Patent project's innovative edge relies on the participatory nature of the web 2.0 environment. This facilitates the creation of online networks and self-selecting citizen experts groups by channelling their knowledge and enthusiasm into expertise that patent examiners can easily use. By using the basic principles of "wikinomics" and web 2.0 tools, the Peer-to Patent project shows how peering, sharing and crowdsourcing expertise can make governments more efficient.

The theoretical underpinnings of the Wiki Government's discourse are closely linked to participatory democracy, where new technologies allow participation on a daily basis rather than through interest groups or voting. Noveck points out, however, that deliberative democracy and participatory democracy are different by their nature. Whereas deliberative democracy emphasizes deliberation and self-expression, participatory democracy emphasizes participation as a means to an end by inviting citizen-experts to engage in information gathering, evaluation and measurement in order to solve a problem.

Noveck's collaborative vision of democratic theory is based on three arguments: collaboration as a distinct form of democratic participation, visual deliberation, and egalitarian self-selection. Designing for collaborative democracy includes a description of visual deliberation, which refers to deliberation (discussion, commenting, sharing knowledge and communicating) in the online environment.

Visual deliberation is an interesting concept that refers to digital platforms as democratic media. In particular, it refers to ways of using the computer screen as a creative interface that 
mirrors the work of participating groups back on themselves. Through the creative interface, experts can organize and interact as networked publics. This makes evaluation and knowledge management tasks intelligible and reduces the problem of information overload.

Noveck also points out that collaboration is distinct from the concept of crowdsourcing. Crowdsourcing refers to the outsourcing of in-house tasks (usually taken care of by an employee) to an undefined, generally large group of people in the form of an open call, whereas collaborative democracy strives for the intentional peer production and group effort that can be seen in, for example, Wikipedia.

However, the idea of new types of communicative governance, i.e., access to information and a broader understanding of transparency, has not been easy to implement. This shift in the democracy paradigm, i.e., taking citizen-experts "in" and the generation of new modes of governance, places greater emphasis on lateral, equal and interactive relationships, like mediation, recognition of interdependencies and networking in democratic governance and practice. This also opens practices of governance to evaluation and criticism.

The culture governance adopted by public organisations addresses several rhetorical promises relating to customer orientation, the opening up of participation channels and the creation of multiple partnership relations between governments and citizens. The concept of wiki government is derived from the whole-of-government approach, which is increasingly looking towards technology as a strategic tool and as an enabler for public service innovation and productivity growth. The author is also well-informed on open source innovation paradigms; external developer communities gathered around open source projects such as Linux, Mozilla et cetera.

In the later chapters, the author broadens the scope to citizen participation in collaborative democracies, and takes examples from European countries. The "Thinking Wiki" chapter presents the main principles of online participation in other areas of governance. This chapter expands beyond the governmental area - and in many ways shows how collaboration and using "group think" and crowd intelligence are also an organic part of today's media ecology. Chapter eight offers lessons for designing better practices to engage the public in governance. They could be information gathering projects, policy wikis, citizen juries or online brainstorming. Here policy wikis and Danish civic juries are presented as European benchmarks in e-governance.

Although the main theme of the book is how to make governance better in the age of web 2.0, it provides food for thought for multiple audiences. For instance, most of the tools and techniques are familiar to journalism educators training future journalists to work in the Web 2.0 media environment. Today's digital journalist has to be ready to crowd-source news, to "mind-cast" through Twitter feeds, work with external developers in open source projects, understand end-user experiences of application programming interfaces - and last but not least, to innovate participatory and interactive digital platforms to enhance click streams and time spent on news media's digital platforms. These skills also seem to apply to an increasing extent to modern civil servants as well. 
Even if the Peer-to-Patent project may sound like a tedious example of e-governance, it has more to offer than just being a successful example of Obama's Open Government Initiative. As participatory democracy strives to create opportunities for all members of the public to make meaningful contributions to decision making, and seeks to broaden the range of people who have access to such opportunities, its democratic nature is also connected to the political economy of innovations. Participatory democracy in a capitalist system is increasingly dependent on expertise and input from outside government. Hence, the Peer-to-Patent project grows into an elegant and innovative story of problem solving, from the solicitation of expertise from close peer groups to open networks of self-organising groups and, finally, the direction in which e-Governance 2.0 is rapidly moving in the United States. That is something that many rigid and slow-moving European governments, their civil servants and journalists should both be aware of and learn from.

Inka Salovaara

Assistant Professor, PhD

Department of Information and Media Studies

Aarhus University, Denmark imvism@hum.au.dk 